\title{
Spatial Tactics in Criminal Courts and the Politics of Legal Technicalities
}

\author{
Marie-Eve Sylvestre \\ Faculty of Law, University of Ottawa, Ottawa, Ontario, Canada; \\ marie-eve.sylvestre@uottawa.ca
}

\section{William Damon and Nicholas Blomley}

\author{
Department of Geography, Simon Fraser University, Burnaby, British Columbia, Canada
}

Céline Bellot

École de service social, Université de Montréal, Montréal, Québec, Canada

\begin{abstract}
This paper documents court-imposed bail and sentencing conditions with spatial dimensions, such as red zones, no contact conditions, curfews and prohibitions to demonstrate, issued in the context of criminal proceedings. These conditional orders, which are growing in importance and have a significant impact on the lives of marginalized groups of people, have not received the attention they deserve in the literature. As opposed to better publicized forms of spatial regulation such as legislation or policing strategies, these conditional orders are a distinctive form of spatial tactic that rely on ancient and routinized rules of criminal procedure and the practices of the courts. In order to understand this spatial tactic, and its impact on marginalized people's rights and uses of spaces, we argue that it is necessary to pay attention to the legal rationalities, knowledge and practices that sustain them.

Résumé: Cet article porte sur le recours grandissant aux conditions à caractère spatial ou géographique, telles que des conditions de ne pas se trouver dans certains lieux publics, de respecter un quadrilatère ou un couvre-feu, une interdiction de communiquer ou encore une interdiction de manifester, imposées dans des ordonnances de mise en liberté ou lors de la détermination de la peine dans le cadre de procédures criminelles. Ces conditions ont des conséquences importantes sur les populations itinérantes et marginalisées et n'ont pas encore été explorées en profondeur dans la littérature. Contrairement à d'autres formes mieux connues de régulation spatiale, telles que la législation ou les stratégies policières, ces ordonnances s'appuient sur des règles de procédure criminelle bien établies et des pratiques judiciaires routinières. Afin de mieux comprendre ces tactiques spatiales ainsi que leurs conséquences sur les droits des personnes marginalisées et leur utilisation des espaces publics, nous suggérons qu'il est impératif de s'intéresser aux rationalités juridiques et aux pratiques qui soutiennent ces ordonnances.
\end{abstract}

Keywords: spatial tactics, criminal courts, bail and sentencing conditions, legal technicalities, marginalized people's rights

\section{Court Geographies}

It is Monday morning in courtroom 301, part of the sprawling 1950s era provincial court house at 222 Main Street, in the heart of Vancouver's Downtown Eastside. The justice is sitting on her dais, in front of the Arms of Her Majesty in Right of 
Canada, and she is presiding over first appearances and bail hearings. A crown counsel and a defense lawyer stand before her. A clerk types quietly. To one side sprawls the court sheriff, who seems busy with a crossword puzzle. A digital clock counts down hours, minutes, and seconds. Besides the prosecutor is a stack of files. A list of names of offenders is marked up on a white board to one side. As the cases progress, the sheriff periodically ticks off the names.

The atmosphere is a curious mix of theatre and the mundane. The majesty of the Crown and the colorful red sash of "Your honor" combine with a highly bureaucratic and routinized process. The cases are dealt with quickly, often taking only a few minutes to process. The assembly line of the criminal justice system rolls forward, with only the occasional moment of confusion and hesitancy (do they have video conferencing in Surrey? Who should we deal with next?). It does not appear to trade in "rights" as such. Rather, the language is a technical one of "show cause", failure to appear, CSOs, "breach", and "time served".

The only variation is that of the alleged offenders who are brought, one by one, before the court, some in person, and others via video feed from a suburban remand center. Most of them are charged with petty offenses (stealing $\$ 159$ worth of meat and cheese from a Safeway store, assaulting a common law partner, using a fake ID, failing to report to a bail supervisor, and so on), with contextual and extenuating circumstances noted quickly by the defense lawyer (grew up in Nova Scotia, a history of abuse, a heroin addiction, a background of mental illness). Standing in a glassed-in prisoners' box, they wear bright red, loose fitting tracksuits and trainers. All are reserved and respectful. Some look worried, others simply confused, perhaps going through withdrawal. They say little, if anything, but appear as bit players in a much larger performance. The judge periodically addresses the accused person, not unkindly, explaining the process, making sure they understand the orders. This is not an overtly punitive discourse, but often one of therapy and help, albeit sternly framed. Each case trails more or less data, as counsel notes criminal records and in particular, breaches of previous court orders. As they depart, they generate more data.

In the cases where the defendants appear and plead not guilty, the court generally grants bail. Bail hearings are often unnecessary because the defense and the prosecution have agreed on the release conditions beforehand, perhaps tweaking them a little in the moment. In many cases, however, the accused plead guilty upon first, second or umpteenth appearance and are readily sentenced. But whether they are released on bail or sentenced after a guilty plea, they are often subject to a set of conditions modeled on the alleged offence, the background of the accused or the entrenched practices of this jurisdiction. These typically include conditions that they "keep the peace and be of good behavior", that they report to a probation officer at times stated in the order and that they notify the court of any change of address. Several also receive "area restrictions" (also referred to as red zones or no go orders), stipulating that they stay away from designated sites, like the home of the complainant, subject to an alleged assault. But these can be broader, requiring persons not to access any named supermarket or pay-day loan outlet in the province of British Columbia, to not enter into a five-block inner city area or even not to be found within entire cities. Some orders contain additional restrictions with spatial consequences, including the requirement to comply with a curfew or to abstain 
from communicating with certain people. In many cases, people are before the court because they have breached one of these requirements. Many, if not all, are uncontested: the accused seems motivated to get out of the overcrowded and often appalling remand facilities, and thus accepts the conditions.

\section{Our Project: Court-imposed Conditional Orders and Legal Technicalities}

We were in the courtroom as part of a research project focusing on conditional orders imposed in the context of criminal proceedings involving marginalized groups of people, including street-level drug users and sex workers, the homeless, and demonstrators, ${ }^{1}$ in four Canadian cities (Montreal, Ottawa, Toronto and Vancouver). We are particularly interested in the use of conditions with spatial dimensions. Some of these conditions specifically rely on a geographic or spatial component (eg prohibiting people from being within the limits of a determined perimeter or from being in a particular place like a park or property generally accessible to the public such as a restaurant or a store), while others have some spatial effects (eg prohibitions to demonstrate or to participate in public meetings or assemblies; curfews, which prohibit the occupation of public spaces during certain hours; no contact orders, which require that people abstain from communicating with a complainant, witness or co-accused with whom they may share common spaces, prohibitions to have a cell phone, which may constrain mobility, etc.). Not all conditional orders entail area restrictions, but most orders have significant (if sometimes unexpected) spatial effects.

In Canada, conditional orders, including spatial restrictions, can be generated at different stages of criminal proceedings, by different actors and under various provisions of the Criminal Code of Canada. They can be both imposed at the pre-trial or post-trial stages. At the pre-trial stage, police officers can impose conditions in a promise to appear delivered to a person in order to compel his or her appearance in court. Justices of the peace can also issue such conditions as part of bail, while the accused are awaiting trial, based on an agreement between the crown and the defense, or after a bail hearing. Judges can also impose conditions post-trial as part of sentencing after the accused pleaded or was found guilty, in a probation order, a conditional sentence order, a jail sentence served in the community, or at parole (under the Corrections and Conditional Release Act). Alternatively, conditions can be imposed independently from criminal proceedings and included in preventative orders to keep the peace issued by a justice of the peace following information from a person who has reasonable grounds to fear that another person might cause personal injury to him or her or to his or her spouse or children, or damage his or her property.

In this project, we focus primarily on court-imposed restrictive orders issued the bail (pre-trial) and sentencing (post-trial) stages in Montreal, Vancouver, Toronto and Ottawa. Our larger project analyzes the nature of these court orders, the legal context in which they are embedded, and their effects on individuals' rights and uses of public spaces, and on the criminal justice system. We use a multidisciplinary and multi-methods framework. In addition to documentary legal analysis, we 
conducted approximately 60 interviews with street-involved drug users and sex workers and interviews with demonstrators subject to court orders, as well as with legal actors (justices of the peace, judges, prosecutors, and defense lawyers) in all four cities. We completed at least 25 hours of court observations in each city before conducting our interviews. Extensive datasets on conditional orders for the past decade have also been obtained. This preliminary paper seeks to introduce the research and reveal the scope and effect of such orders. Both quantitatively and qualitatively, such orders are of growing significance, yet have received almost no institutional or academic scrutiny. Subsequent publications will provide more detailed analysis.

Here, we aim to put our project in conversation with the now well established body of literature on spatial tactics, by which we mean "the use of space as a strategy or technique of power and social control" (Low and Lawrence-Zuniga 2003:30), particularly regarding marginalized or "outsider" groups, such as protestors, and the public poor. In this paper, we identify how this particular form of spatial tactic-as a form of territorial delimitation, distinction and designation-connects with and differs from other forms of spatial tactics.

Our first contribution is to focus on the legal geographies of court-imposed spatial tactics. While there has been a great deal of scholarship on the specific role of the police and of legislatures in regulating public spaces through spatial tactics, very little has been written on the ways in which courts and legal actors working within the criminal justice system (eg judges, prosecutors and defense lawyers) contribute, directly or indirectly, to the production of spatial tactics.

Second, we engage with critical geographic scholarship by emphasizing the importance of understanding better the specifics of legal knowledge and processeswhich we refer to as legal technicalities-in the analysis of the spatial regulation of urban spaces. Following earlier work (Mitchell 1997), scholarship on spatial tactics has tended to emphasize their punitive dimensions (DeVerteuil et al. 2009; O'Sullivan 2012). The motivations for such regulation, it is argued, range from a straightforward desire to remove the unsightly from public view (Bauman 1997; Sibley 1995), to forms of revanchism, fear, revulsion and loathing (England 2008; Smith 1996). This is evidenced in the language that is used to describe the spatial effects of such law. Categories such as "annihilation", "extermination or erasure" or "purification" are commonplace (for a review, see Johnsen and Fitzpatrick 2010).

While sympathetic to much of the spatial tactics literature, we feel that aside from a few notable exceptions (eg Merry 2001) it often has "black-boxed" law (Blomley 2014; Latour 1987), treating legal technique as simply a reflection of cultural and political forces or a tool of governance. According to Latour (1999:304), black-boxing is "the way scientific and technical work is made invisible by its own success. When a machine runs efficiently, when a matter of fact is settled, one need focus only on its inputs and outputs and not on its internal complexity". In this, our work responds to the call for a careful, yet still critical engagement with law's "technicalities" (Blomley 2010; Bourdieu 1980; Johns 2013; Latour 2009; Riles 2005, 2011; Valverde $2003,2009)$. The focus is on the resources, mechanisms and knowledge structures that legal practitioners deploy in order to make sense of their world, it being argued that these have specificity that deserve our attention. We suggest that critical scholars 
should care about technical legal knowledge because it has political and ethical consequences. In other words, when we look inside the black box of law, we find important overlooked practices and rationalities that have significant effects, in particular on the rights of, and uses of space.

Riles (2005:64-70) offers a useful summary of some of the dimensions of legal technicalities, noting that it comprises ideologies (particularly an instrumental, practical and purportedly neutrality mindset); categories of practitioners; a problem-solving paradigm; and a form of reasoning and argumentation, such as the production of stock types of policy arguments. In making sense of such legal complexes, Valverde $(2003: 11)$ suggests that we think of what they "do, how they work, rather than what they are-much less what this all means for globalization, patriarchy, or any other grand practices". She notes the utility of a focus on "the particular effects of the techniques used ... to organize, sort, classify, relate and explain" (2003:14). In sum, the focus is on the technical as "a way of doing legal knowledge" (Riles 2005:976). This may include expert forms of practice, but it also entails often highly routinized and bureaucratic ways of doing things with law.

Scholars and activists have long noted the manner in which the legal regulation of marginalized populations has entailed the strategic use of space, whether in the form of restrictions, zoning or design tools. For example, the police routinely use informal forms of territorial control in their management of inner city populations (Herbert 1997). In efforts to locate, surround or isolate street sex work, they tolerate soliciting in red light districts while preventing it from moving to upper class neighborhoods (Hubbard and Sanders 2003; Matthews 2005). The police further rely on displacement strategies, ranging from orders to disperse (Crawford 2008; Walby and Lippert 2012) to transportation out of town, and sweeps to move on vagrants, while adopting containment techniques, such as the creation of hard and soft zones where protesters are prevented from accessing the target of their grievances, and free-speech zones where protests can legally occur (Gilham 2011; Gilham et al. 2013), the resort to "kettles" (police surrounding protesters), mass arrests and the erection of fences (Dupuis-Déri 2013; Starr and Fernandez 2009).

In turn, provincial and local authorities rely on different forms of spatial banishment or segregation in order to manage the homeless (Mitchell 1997; Wacquant 2008), or to inhibit protests and limit traffic disruption (Blomley 2010; Fernandez 2008). Examples include the creation of prostitution-free zones in the US (Sanchez 2004), or controlled drinking zones in the UK (Johnsen and Fitzpatrick 2007). North American cities have also embarked on urban planning initiatives and architectural changes. These include the redesigning of subway stations (Duneier 1999), changes to street furniture, the enforcement of by-laws and statutes such as the Safe Streets Act regulating the use of public spaces (Sylvestre 2010), limiting protest material or routes, as well as prohibiting certain behaviours in specific places, such as loitering or panhandling at bus stops, or bank machines (Collins and Blomley 2003; O'Grady et al. 2013).

While there are many useful insights to be garnered from this research, it is striking that the overwhelming tendency is to confine the analysis to relatively visible (and occasionally controversial) legislative acts, as opposed to the often more 
quotidian forms of law's technical practice, such as the venerable instrument of bail or the use of probation. In contrast, the spatial restrictions we seek to trace are not exceptional tools or the result of particular legislative interventions or policing strategies. Instead, they are rooted in criminal procedure, relying on the general provisions of the Criminal Code of Canada and on common law principles. They are part of the mundane fabric of petty offences, deriving from the everyday processes and routines of criminal courts and of legal actors. As such, as our opening vignette reveals, they operate quietly and bureaucratically.

While the tendency for geographers and urbanists interested in law might be to treat legal technicalities as uninteresting, Riles (2005:975) insists on their importance, arguing that critical scholars "should care about technical legal devices because the kind of politics that they purport to analyze is encapsulated here". Law's technicalities are political because they are linked to epistemological questions related to the production of knowledge, science and truth (Riles 2005). More specifically, they are political because they serve as crucial "passage points" through which social contests pass. As such, the institutional frameworks they foreground may or may not close the door to certain types of arguments, such as rights. Our data suggest that both in terms of their reach and scope, and their effect, spatial restrictions are pervasive and powerful forms of spatial governance, that have a disparate impact on marginalized groups of people. The very technicalities at work here, moreover, appear to militate against rights-based resistance.

Moreover, such legal techniques often work through particular geographies. For example, Blomley (2010) argues that the manner in which courts regulate and govern the North American sidewalk must be treated on its own terms. He points to the importance of longstanding understandings of "police" power, which operate in quite a different register than prevailing norms of liberal legalism. This quotidian sidewalk rationality, which he dubs "pedestrianism", relies upon a particular understanding of the functions of the sidewalk itself as a space of passage. Yet scholars have tended to overlook such logics, in their rush to frame the sidewalk as a parcel of "public space", or have characterized sidewalk regulation as a straightforward manifestation of social agendas, such as "neoliberalism", thus missing the important work that pedestrianism does in constituting legal space. In a similar vein, Valverde (2009:142) argues that social theorists of scale have much to learn from a study of jurisdiction, which serves as a powerful yet black-boxed mechanism for the sorting of legal phenomena, organizing the where, who, what and how of governance. But this is far from straightforward, she notes: jurisdiction tends to organize the world in some curious and highly contestable ways: "The everyday workings of jurisdiction-which exercise power continuously whether or not anyone is noticing it or challenging it-tend to naturalize the simultaneous operation of quite different, even contradictory, rationalities of legal governance". Similarly, the decision made by a legal actor working at the frontline of the justice system-such as a police officer walking his beat in Vancouver's Downtown Eastside, or a community court prosecutor-to turn to criminal law and criminal procedure, as opposed to other regulatory tools available in their toolbox, triggers a consequential yet easily overlooked chain reaction. 
If legal knowledge "is treated as a phenomenon that is not simply reducible to social pressures and forces, but that has its own epistemological and material autonomy" (Riles 2011:20), critically minded non-lawyers need to be cautious. Eschewing either doctrinalism or a view of legal knowledge as a simple pass-through to an economic or social end, what is needed is an account of the technicality, as Riles puts it, "as something more than just the consequence of wider cultural trends, and as something more robust than putty in the hands of the technocrat" (2005:981). We follow Valverde in her appeal for analyses that are "simultaneously inside and outside law, simultaneously technical and theoretical, legal and socio-legal ... '[t]echnicalities' would be as important in such a study as sociological analyses of power effects" (2009:153).

In what follows, we first show that pre- and post-trial conditions are increasingly large and important parts of Canada's criminal justice system, that those conditions often involve spatial restrictions, and that these have negative consequences on the lives of marginalized people who use public spaces. To understand the nature, scope, and effect of these spatial tactics requires an understanding of legal technicalities. We demonstrate this by documenting the manner in which they derive from particular institutional logics and criminal law practices. This shapes their distinctive hybridity, their complex rationalities and associated spatialities, and their remarkable resistance to rights-based critique.

\section{Significance and Impact of Conditional Orders on Marginalized People}

Recent trends in the administration of justice in Canada suggest that conditional orders, while seemingly technical and somewhat mundane, play an increasingly important role in contemporary criminal justice, occupying a significant amount of police, judicial, and correctional resources, effectively inverting traditional expectations of criminal justice, and affecting a large population of marginalized people. ${ }^{2}$ Yet they have not received the attention that they deserve. In $2011 / 12$, $77 \%$ of adults under correctional supervision were supervised in the community instead of jail, the majority under probation orders (Dauvergne 2012). Probation has been the most common sentence used in adult criminal courts for at least the last decade (in $45 \%$ of all guilty cases in 2012; Statistics Canada 2013). There has been a significant increase in the number of people detained in pre-trial custody awaiting trial or determination of bail across the country (with an average of $53 \%$ of people in provincial/territorial custody being on remand in 2011) (Canadian Civil Liberties Association and Education Trust (CCLA) 2014; Cowper 2012; Ontario Ministry of the Attorney General 2012). As a result, the remand population is now greater than the population in sentenced custody. In particular, failure to comply with conditions (bail) and breach of probation conditions are the two most common types of offence for which adults are remanded (Porter and Calverley 2011:Table 6) and the top two case matters accounting for the most serious offenses in $21.1 \%$ of all criminal court case matters (Public Safety Canada 2012:9). According to data from Statistics Canada, the rate at which police lay charges for failure to comply with a court order increased by 58.3\% nationwide between 2000 and 2012. During the 
same period, the rate of police charging for breach of a probation order increased by $47.4 \%$. These two charges accounted for $75 \%$ of new charges between 2000 and 2012 , driving an overall $4.1 \%$ increase in the rate of charges during a period in which charges for most other criminal offenses decreased or stayed the same (Statistics Canada 2013). Perhaps more strikingly, 44\% of all failure to comply charges and $41 \%$ of all breach of probation charges were single charge cases, where the only alleged criminal wrongdoing was an accused person's failure to abide by their conditions.

A significant proportion of the conditions imposed entail spatial restrictions. For instance, red zones were present in $39.7 \%$ of a one-month Vancouver sample of bail orders (Damon 2014). A survey of bail supervisees in Toronto found that 116 out of 158 respondents (73.4\%) reported having a "no go zone" as a condition of their bail (John Howard Society of Ontario 2013).

The effects of such orders on marginalized groups of people who use public spaces are worth noting. Numerically, a significant proportion of marginalized populations are likely to have experienced their effect (cf Beckett and Herbert 2010a, 2010b:ch 3). Court-imposed conditional orders similarly have a specific impact on poor and marginalized groups who are over represented in pre-trial custody (Kellough and Wortley 2002; Porter and Calverley 2011; Roberts and Doob 1997). In a study conducted on the criminal justice involvement of 2221 homeless adults participating in a Canadian Housing First trial in five Canadian cities, 994 participants (45\%) reported having at least one contact with the justice system in the past six months. Administration of justice offences, including failure to appear in court and breaches of probation orders, were the second most frequent reasons for arrests and charges, accounting for $24 \%$ of the arrests and $19 \%$ of the charges (Roy et al. 2014). At least in Canada, bail conditions appear increasingly to be deployed in an attempt to direct the behavior of those accused, but not found guilty, including through an array of spatial restrictions (eg Balbus 1973; Damon 2014; Esmonde 2003; Moore et al. 2011). A survey of Canadian case law on conditional orders also confirmed the dramatic consequences of these conditions on marginalized groups of people (Sylvestre et al. 2015). Finally, evidence from Vancouver suggests that area restrictions are concentrated in areas of urban marginality, notably, the city's Downtown Eastside (Damon 2014).

The impact of such orders is overwhelming, affecting people's lives at many levels (cf Beckett and Herbert 2010a, 2010b:ch 5). The spatial dimension of these orders is particularly consequential. Let us illustrate this further with examples taken from our interviews. Martine, a young woman in her thirties living in Montreal, using drugs, living with HIV, and engaged in the sex trade, was first charged with communication for the purposes of prostitution in 2002 and then sentenced in 2009 to 30 days in jail followed by a one-year probation order which required her to "keep the peace and be of good behavior", to "notify of any change of address" and "not to found within the perimeter formed by Berri St. (West), Sherbrooke Blvd. (North), Viau St. (East) and Notre-Dame Blvd. (South)". This area roughly corresponds to the Hochelaga-Maisonneuve neighborhood, known by the police for sex trade. Approximately one month after Martine was released on 
probation, she was arrested in the prohibited perimeter. She was charged for breach of a probation condition as well as for communicating for the purposes of prostitution. She was released on bail with stricter conditions, including "not to be found on the entire island of Montreal, except to meet her lawyer and to appear in Court", "to stay at a specific rehabilitation house on the South shore of Montreal" and "to obey the rules and regulations of that house", which included additional therapeutic conditions, such as a curfew. She did not appear in court to be sentenced and was charged for breach of a bail order and a warrant was issued, but 10 months later, she voluntarily appeared in court, pleaded guilty to the charge of failing to comply with a bail order and was sentenced to 55 days of incarceration followed by a two-year probation which maintained her exclusion from the island of Montreal and required that she attended the meetings of Narcotics Anonymous.

In addition to being under police surveillance and carrying a heavy criminal record, Martine was prohibited from going to important community resources essential to her life, health and security, including access to food banks, shelter, medical services and community support, all located on the island of Montreal. More specifically, since she could not get HIV treatment in the suburbs, she obtained the court's permission to attend a doctor's office on the island of Montreal while her area restriction was maintained. In order to do so, however, she had to obtain evidence from public health services that the treatments needed were not offered elsewhere and she regularly had to find someone to drive her through town by car to the doctor's office so she could not be found walking on the streets of Montreal at any time. Meanwhile, Martine reported feeling considerably stressed and anxious. She felt so controlled, she said, she thought "she soon would have to start walking on her hands". Her area restriction was ultimately withdrawn 15 months later as she showed evidence of good behavior.

In another case, Zora, a woman arrested in the context of the protests at the G-20 Summit held in Toronto in June 2010 and charged with conspiracy to commit a mischief over $\$ 5000$, conspiracy to assault police and conspiracy to obstruct the work of police, was released on bail under nine conditions and a recognizance with sureties of several thousands of dollars. Her conditions originally included that she moved out of her residence and remained under house arrest at a relative's residence, except for a series of circumstances including travelling to receive emergency care, meeting with counsel, attending school or in the direct company and supervision of sureties to the point that she felt like she "couldn't be anywhere". It also included a no contact condition with a series of co-accused and a "prohibition to attend, participate or help plan any demonstrations" as well as to "possess any wireless telecommunication device" or to use the Internet. Zora ultimately had her charges withdrawn more than one year later. However, the conditions had tremendous consequences at personal and professional levels, including loss of employment, serious physical and mental health issues, feelings of isolation, and fear of being watched and persecuted, as well as on her participation in political and democratic life where she felt she had been "shut down completely". 


\section{The Politics of Legal Technicalities}

Such effects, however, are easily overlooked, given the black boxing of the technicalities of the criminal law and the lack of consideration of the work conducted by legal actors. While the majority of scholarship has focused on specific legislative acts or policing strategies, our opening vignette makes clear that complex legal dynamics are also at work at both pre-trial and post-trial stages. If we are to understand how conditional orders work, their spatiality, and the Kafkaesque effects upon those subject to them both in terms of rights and uses of space, we need to delve into their specific technical practices and processes.

\section{Court Rules and Procedure}

Court-imposed conditional orders are embedded in ancient, technical and routinized procedural rules. As we shall see, this has a direct impact on legal actors' discretionary powers at different stages of the proceedings and the corresponding spaces of negotiation and representation on behalf of the accused, the forms of reasoning and argumentation and the possibility to challenge court orders based on rights, and the overall visibility of the orders' effects on marginalized people (Myers 2015).

Conditional orders trigger different legal regimes depending on the actors (eg police versus judges) and the moment when they are issued (eg pre-trial versus post-trial). Under the Criminal Code, police officers, who can require that a person comply with a list of prescribed conditions as well as "any other condition" he or she deems "necessary to ensure the safety and security of any victim or of witness to the offence" have less discretion than judges presiding at bail hearings who can also impose "any reasonable condition" he or she considers "desirable" to ensure attendance in court, to ensure the protection and safety of the public having regard to all the circumstances including the likelihood that the accused, if released from custody, will commit a criminal offence, and to maintain the public confidence in the administration of justice.

In contrast, at the sentencing stage, the judge who issues a probation order must impose a set of compulsory conditions, such as the overarching condition to keep the peace and be of good behavior, but may also prescribe optional conditions, including "any reasonable conditions as the court considers desirable for protecting society and for facilitating the offender's successful reintegration into the community" (s.732.1[3.1]Cr.C.). The conditions cannot be primarily punitive and will generally be linked to the particular offence, but need not be (R. v Shoker 2006). In turn, conditional sentence orders, which are equivalent to a jail sentence served in the community, should include overtly punitive conditions that are restrictive of the offender's liberty ( $R$. $v$ Proulx 2000). In addition to the conditions available for probation, the court can prescribe that the offender "comply with such other reasonable conditions as the court considers desirable ... for securing the good conduct of the offender and for preventing a repetition by the offender of the same offence or the commission of other offences" (s.742.3[2][f]Cr.C.).

Both the police and justices of the peace have greater discretionary powers when they are operating at the "front end" of the criminal justice system (pre-trial) than 
post-trial. This has important consequences, given that the majority of conditional orders are issued at this stage. This is in part due to the technical mechanics of the criminal courts. For instance, legal actors have to respect jurisdictional boundaries: the conditions imposed by the police choosing to release an accused based on an undertaking instead of arresting him or her and bringing him or her in front of the court might not be reviewed by the prosecutor responsible for pressing the charges before the accused's first appearance in court days or weeks later. In turn, bail conditions imposed by a justice of the peace can only be challenged in their own separate instance-a bail review held before a judge of the Superior Court-following stringent criteria and with no right of appeal, and their reasonableness cannot be considered in the context of the criminal trial or as a defense to a charge for failure to comply with a bail order. These bail reviews are predictably rare and the expense seldom covered by legal aid, placing the right to appeal largely out of reach of low-income accused. Finally, specific evidentiary rules and exceptions apply. For instance, while the onus is generally on the State to prove that the accused should be detained while awaiting trial, an accused person found in breach of his or her bail order bears the reverse onus to show cause that he or she should be released. Such rules leave bail decisions relatively unchecked and curb the corresponding spaces for negotiation and representation on behalf of the accused.

Technical legal rules also affect the forms of reasoning and argumentation available, limiting the types of arguments that can be made, when they can be made, in front of which fora, and to what avail. The examples of Martine and Zora above suggest that spatial restrictions entail sweeping violations of rights. Yet except for a few notable exceptions, our evidence suggests that bail or sentencing conditions are rarely subjected to constitutional scrutiny (Sylvestre et al. 2015; Trotter 2010). When negotiating or imposing bail or sentencing conditions, arguments are framed within a specific form and follow predetermined legal categories, including narrow offender and offense-driven facts abstracted from most socio-economic context, and a "legal" (as opposed to say, a social or geographical) chronology of events which often includes multiple breaches. These technicalities thus make other considerations such as rights appear irrelevant or nonexistent (Blomley 2010; Riles 2005).

Finally, the fact that conditional orders are deeply seated in venerable, normalized, and general rules of criminal procedure operating quietly and bureaucratically as opposed to specific and more novel or publicized forms of regulation, is likely to render these orders and their effects on marginalized populations less visible. As exposed in our opening vignette, the ordinary and everyday character of criminal procedure, and its entrenchment in the routinized work of the court, creates a sense of naturalness which makes challenges, and rights-based challenges in particular, less likely to occur and be accepted. The history of these particular legal instruments is also likely to have an impact on the possibility of making rights claims. For instance, conditional pretrial release was first introduced in the 1960s in Canada and in the US as a progressive alternative to abuses in pretrial incarceration and bail bonds (Schnacke et al. 2010). As a result, such conditions are perhaps less likely to be viewed as problematic or unconstitutional. In the case of both bail and probation orders, the regularity and familiarity with which legal actors impose restrictive 
conditions is only strengthened by the fact that court actors work with a preestablished form which contains a list of typical, but optional, release conditions next to discrete boxes that can be easily checked. This bureaucratic form, which represents the technicality par excellence, also points to a series of informal practices followed by the courts.

\section{Court Dynamics, Context, and Practices}

The formal, rule based legality of conditional orders can often become compromised by the harsh and messy reality of the criminal law process. For instance, the police and the courts respectively have the duty not to arrest and release, and to release at the earliest reasonable possibility and on least onerous grounds (referred to as the "ladder principle"; R. v Anoussis 2008). Therefore, as a matter of principle, alleged offenders should be granted bail and unconditionally so. In practice, however, serious concerns have been raised that these principles are not being respected (CCLA 2014; Commission on Systemic Racism 2005; Friedland 2004; Trotter 2010). Studies conducted in the UK and in the US estimated that between $40 \%$ and $60 \%$ of bail cases involved release on conditions, showing that bail with conditions has become a middle ground between granting unconditional bail and detention in custody (Raine and Wilson 1997). Based on our own observations and interviews, we found that an accused person who appears in custody at the time of his or her arraignment will almost never be released unconditionally: the accused will either be held in custody until the end of the proceedings or released with conditions (see also CCLA 2014 in which 100\% of defendants were released under some kind of conditions). Contrary to the provisions of the Criminal Code, legal actors assume that if the alleged offender appears in custody, it is necessarily because the police have not deemed it reasonable to release him or her, and thus that they have to be either released on conditions or held in custody: as one prosecutor noted to us: "when a defendant appears in custody, it would be surprising that he or she would be simply released on a condition to keep the peace or be of good behavior". This is so despite the fact that the alleged offender relies on important constitutional rights at such an early stage of the criminal process. In particular, he or she is presumed innocent and is entitled not to be denied reasonable bail according to the Canadian Charter of Rights and Freedoms.

More importantly, such negotiations are embedded in a context which does not provide the necessary space to discuss these issues: there are multiple actors involved, with a high volume of cases, and limited time and resources to put forward claims (Stuntz 1997; Myers 2015), as well as unequal power relationships. Among other things, our research suggests, inter alia, that:

- The alleged offender is held in overcrowded remand facilities while awaiting bail determination. He or she wishes to be released at any cost; after going through multiple adjournments, he or she is ready to plead guilty and be sentenced having understood that "if you plead guilty, you get out today, but if you're innocent, you have to stay in" and wait for a bail hearing. 
- The prosecutor is rarely in a position to assess the significance of the spatial restrictions imposed by the police, to whom they tend to defer for their knowledge of where the "shifting hot spots" are located. He or she might also be conscious of community complaints and police concerns about certain neighborhoods.

- The duty counsel, representing the alleged offender, only has a few minutes to discuss what the conditions entail and they often advise their clients to accept all the conditions the prosecutor consents having regard to the chance of having bail denied altogether at a bail hearing.

- The alleged offender under pressure often forgets crucial details (such as her doctor's office being within the suggested area).

- Judges and prosecutors follow established, if sometimes arbitrary, spatial templates: "I learn the Downtown Eastside Area Restriction: Gore Avenue to the East, Abbot Street to the West, Pender Street to the North and Cordova to the South, from the very beginning" (interview with Vancouver prosecutor).

- Particularly risk-averse justices of the peace with no legal training (Myers and Dhillon 2013) tend to defer to prosecutors and judges are readily convinced that without a series of conditions, they would not have sufficient guarantees to release the offender and prevent the repetition of the alleged offence.

\section{Legal Hybridity}

An exclusive attention to the enforcement of specific statutes, by-laws or policing strategies would not only miss the important work performed by legal actors and court practices, it may also miss the important relationship between the two. Conditional orders are hybrid tools by nature: they are imposed in the context of criminal proceedings, but they have the effect of transforming non-criminal behavior (eg being found in a specific area or in the presence of a specific person, being in public spaces after $10 \mathrm{pm}$, demonstrating, possessing a cell phone) into potential criminal offenses through the enforcement of breaches (ie non-compliance with conditional orders). There are significant overlaps and complementarity between by-law enforcement, which is mostly administrative by nature, and the issuance of conditional orders in criminal proceedings. Preliminary observations and reports from our study suggest that the police use minor infractions, such as jaywalking or loitering, as grounds for stopping inner city residents and running their record, revealing the presence of area restrictions that then allow for more aggressive forms of enforcement. In fact, any by-law or statute violation constitutes in itself a breach of the condition to "keep the peace and be of good behavior" that is usually contained within a bail order, and a mandatory condition of any probation or conditional sentence orders. One consequence for the person subject to conditions of release, therefore, may be that a minor bylaw infraction can be elevated to a more serious (criminal) violation of a court order. This is quite significant given that local authorities are increasingly resorting to administrative law, including provincial and federal statutes as well as bylaws, rather than criminal law as the primary punitive 
normative system in the resolution of conflicts related to the use of public spaces in Canada (Chesnay et al. 2013; Sylvestre et al. 2011). Beckett and Herbert (2010a, $2010 b)$ ) suggest that the combination of criminal, administrative and civil law has the effect of expanding the scope of the criminal justice system. But it may be that criminal law itself is increasingly going through a process of hybridization, incorporating administrative law logics and dispositifs (Vieira Velloso 2013). Again, this has an important impact on rights given that there are less legal guarantees available to challenge a bylaw infraction than a criminal offence.

\section{Courts' Rationalities}

An excavation of the technicalities of court-imposed conditional orders is also useful in that it reframes a discussion of the rationales that animate spatial tactics. To reduce them to logics of "purification" or "banishment" appears too simple. Unlike more politicized forms of intervention, such as "civility ordinances" or prostitution-free zones, conditional orders are embedded in more routinized legal forms, often reliant upon longstanding and ancient legal practices, such as habeas corpus or bail, or powers of government, such as the police power (Blomley 2010; Dubber 2005) with its appeal to "good conduct", and the protection of "community". The rationalities at work here seem to entail a curious mixture of legal imperatives in the Criminal Code and highly discretionary practices, crafted on the fly.

The increased uptake of such tactics is worth noting, and may be explained by the combination of several overlapping and competing rationales of police and courts. For instance, studies conducted with police show that they tend to follow one of the following rationales when imposing conditions of release, and in particular, area restrictions: to aid surveillance, protect victims, neutralize chronic offenders, and help the defendant (MacDonald 2012; Raine and Wilson 1997). While some of these justifications about preventive surveillance, recidivism or therapeutic assistance to the defendants definitely appeared in our interviews with prosecutors and judges, there were also some tensions between the actors. For the police, spatial restrictions are an important policing and investigative tool. They not only allow them to clean certain neighborhoods by keeping "chronic offenders" away, but they also make it much easier for them to arrest an individual quickly without the need to have any reasonable grounds or to collect any evidence with respect to the perpetration of the underlying offence which initially led to the issuance of the conditions. In contrast, prosecutors and judges tend to be concerned about compliance and enforceability of court orders because breaches of court-imposed conditions are legally understood as offences against the administration of justice and a threat to the authority of the court (Murphy 2009). Legal actors also see conditions of release as a lesser evil given that they are concerned with preserving the defendants' liberty and offering an alternative to pre-trial incarceration.

These tensions are consequential in terms of rights and uses of space as competing justifications build on one another and expand surveillance. For instance, after an arrest, the police may sometimes overstep their powers by imposing stricter 
conditions or broader area restrictions than they are entitled, knowing that such conditions are not systematically reviewed. In turn, a judge may tend to accept stricter conditions to avoid sending the accused to a remand center.

\section{Courts' Spatiality}

Finally, what of the spatiality at work here? The spatialization of law makes a difference (Braverman et al. 2014). However, that difference appears complex and hybrid. Our evidence suggests that the conditional order serves as a form of "poverty management", defined as "the creation of spatial and temporal ${ }^{3}$ structures designed to regulate and manage the spillover costs associated with so-called disruptive populations" (Deverteuil et al. 2009:652), with effects that can range from the supportive to punitive. This is supposedly targeted to the individual subjected to these orders in an attempt to produce manageable citizens and responsible selves. $^{4}$

However, if the intent is to act upon the micro-geographies of the individual, the legal actors crafting area restrictions often evidence a poor understanding of the everyday lived realities of space. Their lack of "spatial consciousness" demands more attention. While many of those crafting orders consider their spatial character and geographical impact, there seems to be a mismatch with the lived experience of those subject to them. The effects may be ambiguous or over-broad. What does it mean, for instance, to have a radius around a person given that this person is a moving target; or to have an area restriction in the downtown core given that most poor people are by foot or that most bus routes converge to central locations? What does it mean to be banned from a radius of $300 \mathrm{~m}$ from any college or university when it comprises numerous buildings spread out in a city? The challenges are compounded when an individual is forced to comply with multiple conditions at the same time. Zora, who noted that "the geography of bail conditions is very interesting to [her]", offers one example of this spatial double bind:

I was allowed physically to be on the street [after one of her conditions was modified] but for example, I lived at Brock and Queen at a friend's house and on May 1st there was a demo and I wasn't allowed to be part of any political activity or public demonstration. So I know that the march was going through Parkdale where I was living, so I go to visit my sister to actually physically geographically distance myself from the demonstration for fear that a police officer would think that I am walking towards the demo. So I go to my sister's house, hours passed, and I thought the demo was over, and I don't have a cell phone [as a result of her conditions] so I don't know what's happening. So I decide to head home and I was on Dufferin and College Street and the bus stops and the driver says that everyone has to get off because there is a demonstration about to pass. So I am on the bus and there is like hundreds of people coming up College Street and I have this moment where I am like "I am about to break my bail conditions and I had nothing to do with it." So I ran west away from the demo.

As this story shows, there appears to be a real tension between the geographies of the courtroom and those of the street. Preliminary analysis suggests that the ambiguity inherent in, for example, directing the accused to avoid a "four block radius 
of the intersection of XXXX" (Does this refer to an area of four blocks surrounding an intersection? An area delimited by a radius of four street blocks? Where is the edge of the zone-the center of the street?), combined with discretionary police enforcement practices, and the challenges experienced by those subject to such orders, given histories of mental illness and addiction is such that they seem destined for failure. This is compounded by the fact that mere spatial presence, rather than illegal or criminal behavior, constitutes a violation. While a sit/lie or begging ordinance restricts certain types of behaviours in specified zones, the effects of these spatial restrictions are more pernicious. Perfectly legal activities, such as walking or being in a park, end up being indirectly criminalized and remain largely unchallenged.

While it may be tempting to reduce the geographical effects of conditions of release into simple categories, such as banishment, or purification, the evidence suggests that they structure space in many ways. In some cases, they are highly specific, as in the case of allegations of domestic violence, where the accused is directed to stay away from a named residence. In other cases, they can be remarkably broad (eg being banned from the entire island of Montreal, including its subway stations, or even, in certain cases, being banned from an entire province). Spatial conditions thus appear to serve multiple geo-political ends (cf Walby and Lippert 2012). In an article on police bail, Raine and Wilson (1997) suggested that we distinguish between the following spatial effects: locating (conditions assigning residences); containing (curfews, radius, no contact orders); banning (red zones); and bounding (keep out or away from certain premises). However, we believe the spatial effects to be even more diversified, as noted in the cases above. For instance, one single red zone may at once have the effects of banning as well as confining, indeed in some cases, entrapping individuals in some neighborhoods or areas of town and jeopardizing access to resources and community support. The same measure can also have the effect of displacing, providing temporary relief to a community to the detriment of another. No-contact and association orders can spatially confine people to certain places for fear of being in common or shared space. Indeed, in some cases, it may amount to house arrest. As such, attention to legal technicalities renders more complex our understanding of the spatial effects of court-imposed restrictions.

Finally, the curious absence of rights in relation to these conditional orders, while presumably related to many factors noted above, including the routinized nature of proceedings, may also be a function of their spatialization. Not only do state-scale constitutional rights rarely apply to "low-level" regulations (Valverde 2005) or everyday court processes, but by framing conditions of release with quasi-technical and cartographic constraints, the effect is also to divert attention from the personthe bearer of rights-to the space itself. The governance of space, of course, entails the governance of the person. However, the effect of focusing on the former is to make rights-based arguments that much harder. As Cresswell (1996:159) puts it, spaces "appear to have their own rules, not the rules constructed for them". There is some valuable work in the spatial tactics literature that may offer useful clues concerning the effects of such spatializations on the ability to pursue rights arguments (Carr et al. 2009). Zick (2006), for example, notes the widespread use 
of spatial tactics in the regulation of speech, arguing that it is able to withstand judicial scrutiny because of a view of space as a passive container, rather than as itself constitutive of speech.

\section{Conclusion}

The pervasive reach and effects of these spatial tactics was clearly in evidence when, during a break from our courtroom observations, noted at the outset of the paper, we dropped into a community meeting of current and former drug users in Vancouver's Downtown Eastside. While spatial restrictions are off the academic radar, they were a real and pressing concern to the people in the room. One by one, they recounted, in detail, the often multiple "red zones" they were subject to, the petty tyrannies they experienced with their enforcement by police, their minimal but frustrating encounters with court actors, their daily negotiations and attempts at clandestine concealment when breaching their conditions, and the impacts upon their most fundamental rights. This outsider group could attest to the significance and scope of court geographies: it is thus imperative that critical geographers do the same.

Spatial restrictions included in conditional orders, whether they are issued at pretrial or post-trial stages, have a significant impact on the public poor, often resident in poorer inner city areas. They have grown in importance, yet remain largely unexplored in the literature on spatial tactics. The majority of scholarship has focused on specific policing strategies and practices or legislative acts. However, law is much more than such discrete moments of regulation, and is at work not only in the encounter between the police officer and the homeless beggar. In contrast, the study of conditional orders, a particular form of judicially imposed and judicially monitored spatial tactic, opens up a new research agenda for critical legal geography and urban studies. It draws attention to old yet still extant everyday processes of the courts as well as decisions of legal actors involved in complex, routinized and technical legal regimes that go beyond, yet remain directly connected to, statutory enactments and enforcement practices.

As we embark on this new agenda, our argument is that we need to take law seriously. Our work calls for opening up the black box of legal knowledge and paying renewed attention to its particular forms, rationalities and logics. In the specific case of conditional orders, diving into the legal technicalities expands the conversation on spatial tactics and sheds new light on their negative impact on the rights of individuals subject to them and their uses of space. More specifically, such rights and uses of space are constrained by multiple legal technicalities at work, including the discretion conferred upon legal actors at different stages of legal proceedings, the forms of legal reasoning, the bureaucratic and ancient character of legal instruments, the dynamics and context of the legal process, the multiple overlaps and hybridity of legal regimes, the competing rationalities and discourses of legal actors as well as the actors' poor understanding of space and the very spatiality of their orders.

Spatial tactics are often justified by revanchist discourses of purification, such as broken windows and zero-tolerance narratives (Sylvestre 2013). It is thus tempting 
to characterize them as naked instruments of domination. But, when we take specific legal mechanisms and knowledge seriously, we uncover hidden logics, dynamics and rationales. To understand their effects demands that we treat them on their own terms, rather than simply reducing them to other logics. These elements have significant implications for social justice and, but most importantly, for those who are subject to these orders as they try to resist and challenge them. As such, we cannot leave the technicalities to the technicians.

\section{Acknowledgements}

The authors acknowledge the financial support of the Social Sciences and Humanities Research Council of Canada.

\section{Endnotes}

1 Demonstrators are not primarily or exclusively marginalized for economic reasons, although there are often some overlaps, but we treat them as socially and politically marginal based on their political beliefs and occupation of public spaces.

2 There are indications that the phenomenon is not unique to Canada. For instance, in the US, one-half of the jail population is incarcerated due to probation or parole violations: Beck (2006). In their ground-breaking book, Beckett and Herbert trace the combined effect of off-limits orders, parks exclusions ordinances, and trespass admonishments in Seattle, arguing that the combined effect is "resolutely territorial: they attempt to remove perceived disorder from particular geographic locations" (Beckett and Herbert 2010a:18). They also trace the contingent history of such spatial tactics, their impact on the socially marginal, as well as the manner in which they frequently combine civil and criminal law in overlapping ways while diminishing due process rights. Beckett and Herbert's account is closer to our own in some regards as it pays some attention to legal rules. However, two of the three legal forms they focus on are recent innovations, rather than routinized forms of criminal law. Off-limit orders are blanket prohibitions imposed on certain categories of offenders rather than individualized orders (Hill 2005). Finally, they all seem to be standalone tactics rather than being derived from general provisions of the criminal law.

3 The temporality of conditional orders compounds their effects (Valverde 2014). For instance, any form of release remains in effect until the end of the trial or until the accused is sentenced (unless it is reviewed or revoked), whereas probation orders can be up to three years. The longer someone is required to comply with conditions, the more likely he or she is to be found breaching. The effects of court orders also ramp up over time as individuals subject to court orders are transformed into recidivists, accumulating practically unavoidable breaches.

4 In this regard, our work resonates with recent scholarship on the "individualized spatializations" (Moore et al. 2011:168) of law. Moore et al. (2011) document the use of geographic restrictions imposed at bail in several Canadian drug treatment courts, focusing specifically on legal actors' representations of certain urban spaces known for drug use or vending as bad or unhealthy. Turnbull and Hannah-Moffat (2009) document the impact of house residency conditions imposed to offenders under parole on the production of self-governing subjects as well as the construction of certain place meanings. Yet, this scholarship is scarce and limited to a specific set of measures (eg Munn 2009 for parole or MacDonald 2012 for bail conditions) or to a specific context, such as specialized courts (eg Hannah-Moffat and Maurutto 2012). It also fails to consider the legal technicalities and context in which these orders are embedded.

\section{References}

Balbus I D (1973) The Dialectics of Legal Repression: Black Rebels Before the American Criminal Courts. New York: Russell Sage Foundation 
Bauman Z (1997) Postmodernity and its Discontents. Cambridge: Polity

Beck A (2006) The Importance of Successful Reentry to Jail Population Growth, presented at The Jail Reentry Roundtable, Urban Institute, Washington, slide 2: http://www.urban.org/ sites/default/files/beck.ppt (last accessed 23 May 2015).

Beckett K and Herbert S (2010a) Banished: The New Social Control in Urban America. Oxford: Oxford University Press

Beckett K and Herbert S (2010b) Penal boundaries: Banishment and the expansion of punishment. Law and Social Inquiry 35(1):1-38

Blomley N (2007) How to turn a beggar into a bus stop: Law, traffic and the function of place. Urban Studies 44(9):1697-1712

Blomley N (2008) Civil rights meet civil engineering: Urban public space and traffic logic. Canadian Journal of Law and Society 22(2):55-72

Blomley N (2009) Homelessness and the delusions of property. Urban Geography 30(6):577-590

Blomley N (2010) Rights of Passage: Sidewalks and the Regulation of Public Flow. London: Routledge

Blomley N (2014) The ties that blind: Making fee simple in the British Columbia treaty process. Transactions of the Institute of British Geographers 40(2):168-179

Bourdieu P (1980) The Logic of Practice. Stanford: Stanford University Press

Braverman I, Blomley N, Delaney D and Kedar A (eds) (2014) The Expanding Spaces of Law: A Timely Legal Geography. Stanford: Stanford University Press

Canadian Civil Liberties Association and Education Trust (CCLA) (2014) Set Up to Fail: Bail and the Revolving Door of Pre-trial Detention. Toronto: CCLA

Carr J, Brown E and Herbert S (2009) Inclusion under the law as exclusion from the city: Negotiating the spatial limitation of citizenship in Seattle. Environment and Planning $A$ 41:1962-1978

Chesnay C, Bellot C and Sylvestre M-E (2013) Taming the disorderly one ticket at the time: The penalization of homeless people in Ontario and British Columbia. Canadian Journal of Criminology and Criminal Justice 55(1):161-186

Cole D and Gittens M (1995) Report of the Commission on Systemic Racism in the Ontario Criminal Justice System. Toronto: Queen's Printer for Ontario

Collins D and Blomley N (2003) Private needs and public space: Politics, poverty and antipanhandling by-laws in Canadian cities. In Law Commission of Canada (ed) New Perspectives on the Public-Private Divide (pp 40-67). Vancouver: UBC Press

Commission on Systemic Racism in the Ontario Criminal Justice System (2005) Report of the Commission on Systemic Racism in Ontario Criminal Justice System (Gittens M, Cole D, co-chairs). Toronto: Queen's Printer

Cowper G (2012) A Criminal Justice System for the 21 st Century. Vancouver: BC Justice Reform Initiative

Crawford A (2008) Dispersal powers and the symbolic role of anti-social behaviour legislation. Modern Law Review 7:753-784

Cresswell T (1996) In Place/Out of Place: Geography, Ideology and Transgression. Minneapolis: University of Minnesota Press

Damon W (2014) "Spatial Tactics in Vancouver's Judicial System." Unpublished MA thesis, Simon Fraser University

Dauvergne M (2012) Adult Correctional Statistics in Canada, 2010/2011. Juristat 85-002x

DeVerteuil G, May J and von Mahs J (2009) Complexity not collapse: Recasting the geographies of homelessness in a punitive age. Progress in Human Geography 33(5):646-666

Dubber M (2005) The Police Power. New York: Columbia University Press

Duneier M (1999) Sidewalk. New York: Farrar, Strauss and Giroux

Dupuis-Déri F (ed) (2013) À qui la rue? Répression policière et mouvements sociaux. [To whom does the street belong? Police repression and social movements.]. Montreal: Écosociété

England M (2008) Stay out of drug areas: Drugs, othering and regulation of public space in Seattle, Washington. Space and Polity 12(2):197-213

Esmonde J (2003) Bail, global justice and the limits of dissent. Osgoode Hall Law Journal $41(2): 323-359$

Fernandez L (2008) Policing Dissent: Social Control and the Anti-globalization Movement. New Brunswick: Rutgers University Press

Friedland M (2004) Criminal Justice in Canada Revisited. Criminal Law Quarterly 48:419-462 
Gilham P (2011) Securitizing America: Strategic incapacitation and the policing of protest since the 11 September 2011 terrorist attacks. Sociology Compass 5(7):636-652

Gilham P, Edwards B and Noakes J (2013) Strategic incapacitation and the policing of Occupy Wall Street protests in New York City, 2011. Policing and Society 23(1):81-102

Hannah-Moffat K and Maurutto P (2012) Shifting and targeted forms of penal governance: Bail, punishment and specialized courts. Theoretical Criminology 16(2):201-219

Herbert S (1997) Policing Space: Territoriality and the Los Angeles Police Department. Chicago: University of Chicago Press

Herbert S and Beckett K (2010) "This is home for us": Questioning banishment from the ground up. Social and Cultural Geography 11(3):231-245

Hill G (2005) The use of pre-existing exclusionary zones as probationary conditions for prostitution offenses: A call for the sincere application of heightened scrutiny. Seattle University Law Review 28:173-208

Hubbard P and Sanders T (2003) Making space for sex work: Female street prostitution and the production of urban space. International Journal of Urban and Regional Research 27(1):75-89

Johns F (2013) Non-legality in International Law: Unruly Law. Cambridge: Cambridge University Press

Johnsen S and Fitzpatrick S (2007) The Impact of Enforcement on Street Users in England. Bristol: Policy Press

Johnsen S and Fitzpatrick S (2010) Revanchist sanitisation or ceorcive care? The use of enforcement to combat begging, street drinking and rough sleeping in England. Urban Studies 47(8):1703-1723

John Howard Society of Ontario (2013) Reasonable Bail? Toronto: John Howard Society of Ontario

Kellough G and Wortley S (2002) Remand for plea: The impact of race, pre-trial detention and over-charging on plea bargaining Decisions. British Journal of Criminology 42(1):186-210

Latour B (1987) Science in Action. Cambridge: Harvard University Press

Latour B (1999) Pandora's Hope: Essays on the Reality of Science Studies. Cambridge: Harvard University Press

Latour B (2009) The Making of Law: An Ethnography of the Conseil d'Etat. Cambridge: Polity

Low S and Lawrence-Zuniga D (2003) The Anthropology of Space and Place. Malden: Wiley-Blackwell

MacDonald A (2012) "The Conditions of Area Restrictions in Canadian Cities: Street Sex Work and Access to Public Space." Unpublished MA thesis, University of Ottawa

Matthews R (2005) Policing prostitution-ten years on. British Journal of Criminology 45:877-895

Merry S (2001) Spatial governmentality and the new urban social order. American Anthropologist 103(1):16-29

Mitchell D (1997) The annihilation of space by law: the roots and implications of antihomelessness laws in the United States. Antipode 29(3):303-337

Moore D, Freeman L and Krawczyk M (2011) Spatio-therapeutics: Drug treatment courts and urban space. Social and Legal Studies 20(2):157-172

Munn M (2009) "Falling Out of the Rabbit Hole: Former Long-term Prisoners' Negotiation of Release, Re-entry and Resettlement." Unpublished PhD thesis, University of Ottawa

Murphy E (2009) Manufacturing crime: Process, pretext and criminal justice. Georgetown Law Journal 97:1435-1507

Myers N (2015) Who said anything about justice? Bail court and the culture of adjournment. Canadian Journal of Law and Society 30:127-146

Myers N and Dhillon S (2013) The criminal offence of entering any shoppers drug mart in Ontario: Criminalizing ordinary behaviour with youth bail conditions. Canadian Journal of Criminology and Criminal Justice 55(2):187-214

Ontario Ministry of the Attorney General (2012) Bail Expert Table Recommendations. Ontario: Canada: Ministry of Justice Province of Ontario

O'Grady W, Gaetz S and Buccieri K (2013) "Tickets ... and more tickets: A case study of the enforcement of the Ontario Safe Streets Act. Canadian Public Policy 39(4):541-558

O'Sullivan E (2012) Varieties of punitiveness in Europe: Homelessness and urban marginality. European Journal of Homelessness 6(2):69-97 
Porter L and Calverley D (2011) Trends in the use of remand in Canada. Juristat. http://www. statcan.gc.ca/pub/85-002-x/2011001/article/11440-eng.pdf (last accessed 26 April 2015)

Public Safety Canada (2012) Corrections and Conditional Release Statistical Overview. Ottawa: Public Safety Canada. http://www.publicsafety.gc.ca/cnt/rsrcs/pblctns/2012-ccrs/2012ccrs-eng.pdf (last accessed 26 April 2015)

Raine J W and Wilson M J (1997) Police bail with conditions: Perspectives on the use, misuse, and consequences of a new police power. British Journal of Criminology 37:593-607

Riles A (2005) A new agenda for the cultural study of law: Taking on the technicalities. Buffalo Law Review 53:973-1033

Roberts J and Doob A (1997) Race, ethnicity, and criminal justice in Canada. In M Tonry (ed) Ethnicity, Crime, and Immigration: Comparative and Cross-National Perspectives (pp 469-522). Chicago: University of Chicago Press

Riles A (2011) Collateral Knowledge: Legal Reasoning in the Global Financial Markets. Chicago: University of Chicago Press

Roy L, Crocker A, Nicholls T, Latimer E, Gozdzik A, O'Campo P and Rae J (2014) “Profiles of Criminal Justice Involvement of Mentally III Homeless Adults." Unpublished manuscript

Sanchez L (2004) The global e-rotic subject, the ban, and the prostitute-free zone: Sex work and the theory of differential exclusion. Environment and Planning D 22:861-883

Schnacke T, Jones M and Brooker C (2010) The History of Bail and Pretrial Release. Pretrial Justice Institute

Sibley D (1995) Geographies of Exclusion. London: Routledge

Smith N (1996) The New Urban Frontier: Gentrification and the Revanchist City. New York: Routledge

Starr A and Fernandez L (2009) Legal control and resistance post-Seattle. Social Justice 36(1):41-60

Statistics Canada (2013) Table 252-0053 Adult Criminal Courts, Number of Cases and Charges by Type of Decision, Annual (number). CANSIM. http://www5.statcan.gc.ca/ cansim/a26?lang=eng\&id=2520053 (last accessed 26 April 2015)

Stuntz W (1997) The uneasy relationship between criminal procedure and criminal justice. Yale Law Journal 107(1):1-76

Sylvestre M-E (2010) Disorder and public spaces in Montreal, Canada: Repression (and resistance) through law, politics and police discretion. Urban Geography 31(6):803-824

Sylvestre M-E (2013) Narratives of punitiveness: Neoliberalism, class interests and the politics of social exclusion. European Journal of Homelessness 7(2):363-369

Sylvestre M-E, Bellot C, Couture-Ménard P A and Tremblay A (2011) Le droit est aussi une question de visibilité: occupation des espaces publics et parcours judiciaires des personnes itinérantes à Montréal et à Ottawa. Canadian Journal Law and Society 26(3):531-561

Sylvestre M-E, Bernier D and Bellot C (2015) Red zone orders in criminal courts and the reproduction of socio-economic inequality. Oñati Socio-Legal Series 5(1):280-297

Trotter G (2010) The Law of Bail in Canada (3rd edn). Toronto: Carswell

Turnbull S and Hannah-Moffat K (2009) Under these conditions. British Journal of Criminology 49:532-551

Valverde M (2003) Law's dream of a common knowledge. Princeton: Princeton University Press

Valverde M (2005) Taking 'land use' seriously: Toward an ontology of municipal law. Law Text Culture 9:34-59

Valverde M (2009) Jurisdiction and scale: Legal technicalities as resources for theory. Social and Legal Studies 18(2):139-157

Valverde M (2014) "Time thickens, takes on flesh": Spatiotemporal dynamics in law. In I Braverman, N Blomley, D Delaney and A Kedar (eds) The Expanding Spaces of Law: A Timely Legal Geography (pp 53-76). Stanford: Stanford University Press

Vieira Velloso J G (2013) Beyond criminocentric dogmatism: Mapping institutional forms of punishment in contemporary societies. Punishment and Society 15(2):166-186

Wacquant L (2008) Urban Outcasts. Cambridge: Polity

Walby K and Lippert R (2012) Spatial regulation, dispersal, and the aesthethics of the city: Conservation officer policing of homeless people in Ottawa, Canada. Antipode 44(3):1015-1033

Zick T (2006) Speech and spatial tactics. Texas Law Review 84(3):581-651 